\title{
A pilot study on diagnosing laryngopharyngeal reflux disease by pharyngeal pH probe monitoring
}

\author{
Larengofarengeal reflü hastalığının tanısında farengeal pH probu ile pilot bir çalışma \\ Mümtaz Taner Torun, Murat Gümüşsoy, İbrahim Çukurova, İ. Burak Arslan, Tolga Kandoğan \\ Department of Otolaryngology, Tepecik Training and Research Hospital, Izmir, Turkey
}

\begin{abstract}
Objective: We aimed to evaluate (laryngopharyngeal reflux) LPR disease group and group with healthy volunteers and compare results obtained using Dx $\mathrm{pH}$ probe in the diagnosis of LPR disease.

Methods: Fifty-seven LPR patients with typical scores of reflux symptom index (RSI) and reflux finding scoring (RFS) system and 20 healthy volunteers without laryngopharyngeal symptoms and physical examination findings were included in the study after excluding other concomitant diseases. All patients were requested to complete RSI and RFS forms. Healthy volunteers, with RSI $<13$ and RFS $<7$ constituted the control group and LPR group consisted of patients with RSI $>13$ and RFS $>7$. Dx $\mathrm{pH}$ probes were applied to each group. Fisher's exact test, Shapiro-Wilk test, T test and Mann-Whitney test were used for statistical analysis. A p value $<0.05$ was considered to be significant.

Results: Between the two groups, there was no statistically significant difference in terms of age, sex and body mass index (BMI). Mean $\mathrm{pHs}$ were estimated as 6.97 in healthy volunteers and 6.27 in the LPR group $(\mathrm{p}<0.05)$. $\mathrm{pH}$ events were calculated separately for $\mathrm{pHs}<5.5$ and $<5.0$. Besides, acid exposure times were estimated and compared in two groups. There was a significant statistical difference between two groups $(\mathrm{p}<0.05)$. In addition, $\mathrm{pH}$ events in the upright and supine position were calculated separately and intra- and intergroup comparisons were made. Any statistical significant difference was not detected in intragroup comparisons $(\mathrm{p}>0.05)$, despite a statistically significant intergroup difference $(\mathrm{p}<0.05)$. Conclusion: $\mathrm{Dx} \mathrm{pH}$ probe was found to be an alternative to other methods commonly used in the diagnosis of LPR. When compared with RSI and RFS scores, Dx $\mathrm{pH}$ probes provided consistent and accurate data. Dx $\mathrm{pH}$ probe application can be an alternative to frequently used diagnostic methods for LPR.
\end{abstract}

Key words: Laryngopharyngeal reflux, reflux symptom index, reflux finding score, pharyngeal $\mathrm{pH}$ probe.

Gastroesophageal reflux (GER) is a spontaneous and effortless regurgitation of gastric contents into esophagus. However laryngopharyngeal reflux (LPR) is an atypical

\begin{abstract}
Özet
Amaç: Çalışmamızda larengofarengeal reflü (LFR) hastalığı olan ve sağlıklı iki grup değerlendirilerek, Dx pH probunun LPR tanısında sonuçlarını karşılaştırmayı amaçladık.

Yöntem: Diğer hastalıklar ekarte edildikten sonra hem reflü semptom indeksi (RSI) hem de reflü bulgu skoru (RBS) ile tipik skorlara sahip 57 LFR olgusu ile larengofarengeal yakınması ve fizik muayene bulguları olmayan 20 sağlıklı gönüllü çalışmaya alındı. Tüm olgulara RSI ve RBS formları dolduruldu. RSİ $<13$ ve RBS $<7$ olanlar sağlıklı grubu oluştururken RSİ $>13$ ve RBS $>7$ olanlar LFR grubunu oluşturdu. İki gruba Dx pH probu takılarak veriler elde edildi. İstatistiksel değerlendirmede Fisher'in kesin olasılık testi, Shapiro-Wilk testi, T testi ve Mann-Whitney testi kullanıldı. $\mathrm{p}<0.05$ istatistiksel olarak anlamlı kabul edildi.

Bulgular: İki grup arasında yaş, cinsiyet ve vücut kitle indeksi bakımından istatistiksel fark saptanmadı. Sağlıklı gönüllülerde ortalama pH değeri 6.97 saptanırken hasta grupta 6.27 olarak hesaplandı $(\mathrm{p}<0.05)$. $\mathrm{pH}$ olayları, $\mathrm{pH}<5.5$ ve $\mathrm{pH}<5.0$ değerleri için ayrı ayrı hesaplandı; asit maruziyet süreleri de değerlendirilerek iki grup arasında karşılaştırıldığında istatistiksel olarak anlamlı fark saptandı $(\mathrm{p}<0.05)$. Ayrıca iki grubun $\mathrm{pH}$ olayları dik ve sırtüstü pozisyonlarda ayrı ayrı hesaplanarak hem kendi içlerinde hem de gruplar arasında karşılaştırma yapıldı. Kendi içlerindeki kıyaslamalarda istatistiksel olarak anlamlı fark saptanamadı ( $>0.05)$, ancak iki grup arasında bu kıyaslamada istatistiksel olarak anlamlı fark saptandı $(\mathrm{p}<0.05)$.

Sonuç: Dx pH probu verileri RSİ ve RBS değerleri ile kıyaslandığında tutarlı ve doğru sonuçlar elde edilmiştir. Larengofarengeal reflü tanısında sık kullanılan diğger yöntemlere alternatif olabileceği görülmüştür.
\end{abstract}

Anahtar sözcükler: Larengofarengeal reflü, reflü semptom indeksi, reflü bulgu skoru, farengeal $\mathrm{pH}$ probu.
Correspondence: Murat Gümüşsoy, MD. Department of Otorhinolaryngology, Tepecik Training and Research Hospital, Gaziler Caddesi, No: 468, Yenişehir, İzmir, Turkey. e-mail: mgumussoy@hotmail.com

Received: May 23, 2013; Accepted: July 2, 2013; Published online: January 29, 2014 form of GER in which gastric contents severely regurgitate up to upper esophageal sphincter without retching or vomiting. Retrosternal burning sensation and regurgitation are
Online available at: www.jmedupdates.org doi: $10.2399 /$ jmu. 2013003004 QR code:

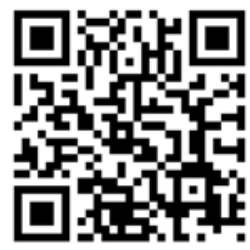


not observed in the majority of cases with LPR when compared with GER. ${ }^{[1-3]}$

Transnasal fiberoptic laryngeal examination, standard acid reflux test, dual-probe 24-hour $\mathrm{pH}$ monitorization, esophageal manometry, multi-channel intraluminal impedance test, $\mathrm{Dx} \mathrm{pH}$ probe, Bravo $\mathrm{pH}$ probe and laryngeal sensitivity tests are preferred diagnostic test methods for LPR. Despite all of these diagnostic tests, a $100 \%$ sensitive and specific single method leading to correct diagnosis is lacking. ${ }^{[-7]}$ Thanks to scoring system for symptomatic severity and endoscopic findings in LPR, difference between posttreatment state and baseline has become apparent. Belafsky et al. ${ }^{[2,3]}$ formulated reflux finding scoring (RFS) system based on reflux symptom index (RSI) and fiberoptic laryngoscopic findings and conducted investigations on its applicability as a diagnostic tool in LPR.

Recently developed $\mathrm{Ph}$ measurement system ( $\mathrm{Dx} \mathrm{pH})$ using minimally invasive oropharyngeal probe can evaluate refluxate material both in fluid and gaseous forms. Its easy applicability and more specific identification of pseudoreflux episodes are among advantages of $\mathrm{Dx} \mathrm{pH} .^{[4-6]}$ In our study we applied $\mathrm{Dx} \mathrm{pH}$ probe for cases evaluated by RSI and RFS and aimed to share information related to its diagnostic efficacy in LPR and our clinical outcomes.

\section{Materials and Methods}

Fifty-seven LPR patients with typical scores of RSI and RFS but without any concomitant diseases who consulted to our outpatient clinics between November 2010 and October 2012 and also 20 healthy volunteers without any laryngopharyngeal symptoms and related physical examination findings were included in the study and body mass indexes (BMIs) of all participants were calculated.

Cases under treatment for the previous one month with the established diagnosis of LPR and/or GER, suspect cases with laryngeal malignancies, those with a history of laryngeal surgery or gastrointestinal system diseases are excluded from the study. All cases underwent routine examinations, then they were requested to respond to a RSI form which consisted of 9 items (Table 1). Endoscopic findings were scored and evaluated based on flexible fiberoptic examination results and a RFS form was completed (Table 2). In order to support our study with objective data, cases with RSI $>13$ and RFS $>7$ were considered as LPR patients and included in the study.

Before the procedure, oropharyngeal probe was calibrated in buffer solutions with $\mathrm{pH} 4$ and 7 in accordance with the manufacturer's recommendations. Oropharyngeal
Table 1. Reflux symptom index (RSI)

\begin{tabular}{|l|l|l|l|l|l|l|}
\hline $\begin{array}{l}\text { Within the last month, } \\
\text { how did the following } \\
\text { problems affect you? }\end{array}$ & \multicolumn{5}{|l|}{ 5: Extremely at all } \\
\hline Hoarseness or voice problems & $\mathbf{0}$ & $\mathbf{1}$ & $\mathbf{2}$ & $\mathbf{3}$ & $\mathbf{4}$ & $\mathbf{5}$ \\
\hline Need for throat clearing & & & & & & \\
\hline Excess throat mucus or postnasal drip & & & & & & \\
\hline Difficulty swallowing food/liquids or pills & & & & & & \\
\hline Breathing difficulties or choking episodes & & & & & & \\
\hline Troublesome or annoying coughing & & & & & & \\
\hline $\begin{array}{l}\text { Sensations of something sticking or a } \\
\text { lump in your throat }\end{array}$ & & & & & & \\
\hline $\begin{array}{l}\text { Heartburn, chest pain, indigestion or } \\
\text { stomach acid coming up to mouth }\end{array}$ & & & & & & \\
\hline
\end{tabular}

$\mathrm{pH}$ probe was inserted under direct vision and LED on its tip was engaged inside the cheek at the level of uvula. Recordings were retrieved for 24 hours and transferred into a computerized system. Data were analyzed and evaluated using Restecht Data Viewer program.

Table 2. Reflux finding score (RFS)

\begin{tabular}{ll}
\hline Pseudosulcus (infraglottic edema) & \\
& $0:$ Absent \\
& $2:$ Present \\
\hline Ventricular obliteration & $0:$ Absent \\
& $2:$ Partial \\
& $4:$ Complete \\
\hline Erythema/hyperemia & $0:$ Absent \\
& $2:$ Arytenoids only \\
& $4:$ Diffuse \\
\hline Vocal cord edema & $0:$ Absent \\
& $1:$ Mild \\
& $2:$ Moderate \\
& $3:$ Severe \\
& $4:$ Polypoid \\
\hline Diffuse laryngeal edema & $0:$ Absent \\
& $1:$ Mild \\
& $2:$ Moderate \\
& $3:$ Severe \\
& $4:$ Obstructing \\
\hline Posterior commissure hypertrophy & $0:$ Absent \\
& $1:$ Mild \\
& $2:$ Moderate \\
$3:$ Severe \\
$4:$ Obstructing \\
\hline Granuloma/granulation & $0:$ Absent \\
& $2:$ Present \\
\hline Thick endolaryngeal mucus & $0:$ Absent \\
& $2:$ Present \\
\hline
\end{tabular}


Mean values of 24-hour $\mathrm{pH}$ recordings, total number of $\mathrm{pH}$ episodes, acid exposure times (the longest and total) related to the control and LPR groups measured by Dx $\mathrm{pH}$ probe were evaluated separately. Data of both groups were compared with each other and their statistical analyses were performed. To analyze relationship between reflux attacks in the upright and supine positions, intragroup analysis of the data related to individual $\mathrm{pH}$ events occurring in the upright and supine positions in both groups was performed and their statistical analysis was conducted.

\section{Statistical Evaluation}

All data obtained were entered into SPSS (Statistical Package for Social Sciences) Windows 15.0 program (SPSS Inc., Chicago, IL, USA). Numerical data were expressed as number of cases and percentages. Fisher's exact probability test was performed for categorical comparisons with appropriate corrections. For compatibility analysis of normality of distribution in continuous data Shapiro-Wilk tests were performed and data demonstrating normal distribution were assessed with parametric $T$ test. Data with non-normal distribution non-parametric Mann-Whitney $\mathrm{U}$ test was used. The p values smaller than 0.05 were considered as statistically significant.

\section{Results}

Laryngopharyngeal reflux group consisted of total of 57 [12 (21\%) men and 45 (79\%) women] patients and the control group included 20 healthy volunteers [8 (40\%) men and 12 (60\%) women]. Mean ages of the control and the LPR groups were 44.8 (range: $22-71$ ) years and 44.8 (range: 18 80) years, respectively. A statistically significant difference was not detected between both groups as for gender and age distribution ( $>0.05)$ (Table 3).

Body mass indexes of the healthy volunteers ranged between 20-38 (median: 26.8) kg/m². Four cases were overweight (BMI>30 kg/m ${ }^{2}$ ) and the corresponding BMIs for LPR group were 16.7-40.9 (median: 26.4) $\mathrm{kg} / \mathrm{m}^{2}$ and 13 cases were overweight. Any statistically significant difference was not found as for BMIs between both groups $(\mathrm{p}>0.05)$.

Reflux symptom indexes of the healthy volunteers and the LPR group changed between 1-10 (median: 4.0) and 13-39 (median: 20.0), respectively. A statistically significant difference was found between both groups as for RSI values $(\mathrm{p}<0.05)$ (Table 4).

Reflux finding scores of the healthy volunteers and the LPR group varied between 0-4 (median: 1.45) and 7-11
Table 3. Distribution of the study group according to gender of the participants.

\begin{tabular}{lcccc}
\hline & Male & Female & Total & p value \\
\hline Healthy volunteers & $8(40 \%)$ & $12(60 \%)$ & $20(100 \%)$ & $p>0.05$ \\
LPR group & $12(21 \%)$ & $45(79 \%)$ & $57(100 \%)$ & \\
\hline
\end{tabular}

(median: 8.28), respectively. A statistically significant difference was found between both groups regarding RFS values $(\mathrm{p}<0.05)$ (Table 4).

Median 24-hour $\mathrm{pH}$ values of the healthy volunteers and the LPR group were estimated as 6.7 (range: 6.09-7.64) and 6.27 (range: 5.6-6.88), respectively. A statistically significant difference was detected between median $\mathrm{pH}$ values of both groups $(\mathrm{p}<0.05)$ (Table 4$)$.

In the group with healthy volunteers, any $\mathrm{pH}$-events were not detected in $12(60 \%)$ cases, while in 8 cases a total of $49 \mathrm{pH}$ events were detected (median: 2.45; range: 1-13 $\mathrm{pH}$ events). In the LPR group, a total of 6094 (median: 106.91; range: $4-382 \mathrm{pH}$ events) $\mathrm{pH}$ events were detected with a statistically significant difference between groups $(\mathrm{p}<0.05)$ (Table 4).

$\mathrm{Ph}$ events recorded in the supine and upright positions among healthy volunteers were analyzed separately and we found that $30(61.2 \%)$ of $49 \mathrm{pH}$ events had happened in the supine and 19 (38.8\%) of them in the upright position. Intragroup comparisons of these data were evaluated and any statistically significant difference was not noted (p>0.05). However in the LPR group 3257 (53.45\%) of $6094 \mathrm{pH}$ events occurred in the supine and 2837 (46.55\%) of them in the upright position. Intragroup comparisons of these data also could not reveal any statistically significant intragroup difference ( $\mathrm{p}>0.05)$.

Total acid exposure time of all healthy volunteers was 1154 (median: 57.7) secs. When all cases in this group were analyzed individually, the longest acid exposure time was

Table 4. Statistical comparisons among mean RSI, RFS, pH values and the total number of $\mathrm{pH}$ events of both groups.

\begin{tabular}{lccc}
\hline & $\begin{array}{c}\text { Control } \\
\text { group }\end{array}$ & $\begin{array}{c}\text { LPR } \\
\text { group }\end{array}$ & $\begin{array}{c}\mathbf{p} \\
\text { value }\end{array}$ \\
\hline RSI (mean) & 4.0 & 20.0 & $\mathrm{p}<0.05$ \\
RBS (mean) & 1.45 & 8.28 & $\mathrm{p}<0.05$ \\
pH & 6.97 & 6.27 & $\mathrm{p}<0.05$ \\
Total number of pH events & 49 & 6094 & $\mathrm{p}<0.05$ \\
Number of pH events & 2.45 & 106.91 & $\mathrm{p}<0.05$ \\
Total acid exposure time (mean) & 57.7 & 6320.86 & $\mathrm{p}<0.05$ \\
\hline
\end{tabular}


226 (median: 28.45) secs. In the LPR group, total acid exposure time was 360,289 secs (median: 6320.86) secs. All these cases in this group were analyzed individually and the longest exposure time was estimated as 895 (median: 647.23) secs. Averages of total acid exposure times of the healthy volunteers and the LPR group were 57.7 and 6320.86 secs, while the average of the longest exposure times of the corresponding groups were 28.45 and 647.23 secs, respectively with a statistically significant intergroup difference $(\mathrm{p}<0.05)$.

\section{Discussion}

Laryngopharyngeal reflux and GER occurs as a result of mucosal damage due to acid and pepsin exposure, however laryngeal mucosa is more responsive to acid and pepsin exposure relative to the esophageal mucosa. ${ }^{[8-11]}$ Cellular damage occurs when acidity of the esophageal and laryngeal epithelium drop below pHs 4 and 5, respectively. Therefore, LPR symptoms might arise, before severity of acidic reflux is not sufficient to induce development of esophagitis. ${ }^{[12]}$ Contrary to GER, complaints of heartburn and regurgitation are not frequently encountered in LPR. ${ }^{[13,14]}$ Ossakow et al. ${ }^{[1]]}$ reported that patients with complaints of reflux had been either treated in the outpatient clinics of ENT (earnose and throat) ( $n=63)$ or gastroenterology (GE) $(n=36)$. The authors also compared signs and symptoms of the cases and detected episodes of hoarseness in 100\% of ENT cases (in none of GE patients), while the corresponding rates of heartburn in the ENT and GE groups were reported in 6 and $89 \%$ of the cases, respectively. In a different study, complaints of heartburn could not be demonstrated in more than $50 \%$ of cases with LPR. In LPR, pharyngeal and voice complaints are in the foreground. In a large series of patients with LPR, symptoms as dysphonia (71\%), chronic coughing (51\%), globus sensation and chronic throat cleaning $(42 \%)$ have been reported. ${ }^{[8]}$

Various diagnostic criteria for LPR have been proposed. In a multi-centered study performed on 138 cases in ENT clinics of Turkey, LPR positivity was found to be $47 \%$ in 138 cases with normal physical examination (PE) findings and $62 \%$ in suspect reflux patients mostly with posterior laryngitis as assessed by 24-hour $\mathrm{pH}$-monitoring tests. ${ }^{[15]}$ The prevalent method used in the diagnosis and treatment of LPR is interrogation of LPR symptoms and signs which formulate diagnosis and treatment. Conservative or empirical treatment is among these methods and any standardization has not been established yet. Uncertainties still exist about indication for the initiation of LPR treatment, drugdose selections, durations of treatment and monitorization periods. Currently, practical algorithms of history taking and differential diagnosis to be used for the diagnosis of LPR are needed. ${ }^{[5,8,10,13,15]}$

In order to be able to evaluate LPR symptoms and their severity Belafsky et al. ${ }^{[\beta]}$ described a reflux finding scoring (RFS) system which interrogated frequently encountered 8 symptoms of LPR. Scores of RFS ranges from 0 to 26 points. In their investigation of 40 cases with a diagnosis of LPR as assessed by 24-hour dual-probe $\mathrm{pH}$ monitorization tests, average pretreatment RFS score was found to be 11.5 pts, while the corresponding RFS scores at postoperative 2nd, 4th and 6th months were 9.3, 7.3 and 6.1 pts, respectively. In the control group with 40 participants without any past history of LPR, median RFS score was detected to be 5.2 (range: 3.6-6.8) pts and cases with scores of $\geq 7$ were defined as LPR with a $95 \%$ predictive accuracy. In many studies performed, reproducible RFS system was used..$^{[16-18]}$ Oelschlager et al. ${ }^{[19]}$ reported response rates to acid suppressive therapy as $83 \%$ in patients with RFSs above 7 pts and abnormal hypopharyngal $\mathrm{pH}$ monitorization findings and as $44 \%$ in asymptomatic cases and evaluated RFS and hypopharyngeal $\mathrm{pH}$ monitorization as complementary methods in the diagnosis of LPR. Despite different scoring systems, RFS is a reliable and developable method in the objective assessment of LPR. This scoring system provides a total reflux score which evaluates glottic and supraglottic anatomy in combination. ${ }^{[3,16-19]}$

In consideration of different symptomatic manifestations of GER and LPR, Belafsky et al. ${ }^{[2]}$ developed a 9-item RSI which evaluates symptoms of LPR. With the intention to reveal sensitivity and validity of RSI, standard dual-probe $\mathrm{pH}$ monitorization procedures were applied on 25 cases to make a diagnosis of LPR. Subsequently, the patients completed RSI and voice handicap index (VHI) forms and the same forms were filled up by the same participants at posttreatment 6th months and average pre- and posttreatment RSI scores were compared (20.9 and 12.8 pts, respectively). In the same study, median RSI score in the asymptomatic control group was found to be 11.6 (range: 9.7-13.6) pts. Therefore, RSI values above 13 pts were regarded as abnormal findings. In many studies performed reproducible RSI scores were used..$^{[16-1,20]}$

Even though RSI and RFS have been used as separate diagnostic criteria, in our study cases meeting the requirements of both criteria (LPR if RSI $>13$, and RFS $>7$ and healthy if RSI $<13$ and RFS $<7$ ) were included in the study. Besides RSI scores of both groups were compared and increases in the patient group were found to be statistically 
significant $(\mathrm{p}<0.05)$. The same comparative assessments were done for RFS and increases in RFS values were regarded as statistically significant as is the case with RSI $(\mathrm{p}<0.05)$. This observation have demonstrated that both scoring systems can accurately and realiably discriminate between the LPR and the healthy control groups.

Cherry and Marguiles ${ }^{[2]}$ and Malcomson ${ }^{[2]}$ firstly described (1968) LPR which is one of the extraesophageal manifestations of GER and since then hundreds of investigations have been performed related to diagnosis and treatment of LPR. Dual-channel 24-hour esophageal monitorization technique has the highest diagnostic sensitivity and specificity for LPR. Diagnostic tools for GER including barium esophagography, esophagoscopy-guided biopsy, acid perfusion test (Bernstein) and radionuclide scanning tests cannot predict LPR. Sensitivity and specificity of 24-hour $\mathrm{pH}$ monitorization are nearly 90 and $98 \%$, respectively and as a result this technique has been currently regarded as a gold standard due to its highest diagnostic accuracy for reflux in GERD, rather than LPR ${ }^{[8,13,14]}$ Reported diagnostic accuracy rates of 24-hour $\mathrm{pH}$ monitorization in determining laryngeal problems related to GER have ranged between 17.5 and 78.8 percent. Technological ultrastructure required for 24-hour $\mathrm{pH}$ monitorization, higher cost of the technique, procedure-related discomfort felt by the patient, potential problems in the placement of the probe, loss of mucosal contact, displacement of the probe, changes in $\mathrm{pH}$ due to oral intake, intermittent drying and wetting of the proximal probe are among the main culprits for the false predictive test results. Besides inability to obtain similar results in recurrent tests performed at different time intervals has been cited as disadvantages of this test. ${ }^{[8,10,14-16]}$

As an innovative diagnostic tool, $\mathrm{Dx} \mathrm{pH}$ probe has been designed quite differently from conventional $\mathrm{pH}$ probes. Its teardrop-shaped sensor tip (conventional probes has a sidesensor) can function in the pharyngeal cavity without any risk of desiccation. Vapour condensation during expiration keeps the sensor humidified. Thus, false measurements due to drying up in the probe have been minimalized when compared with dual-channel $\mathrm{pH}$ monitorization. Hydrogen ion concentration measurement system encased in its electrode can evaluate refluxate material both in gaseous and liquid forms and also it can more reliably detect pseudoreflux events which cannot be discerned during dual-channel 24-hour $\mathrm{pH}$ monitorization studies. Thanks to this new technology, oropharyngeal $\mathrm{pH}$ values can be measured 2 times per second. Also it appears to be a superior technique over 24-hour esophageal $\mathrm{pH}$ monitorization which can only measure $\mathrm{pH}$ at every 3-4 seconds. Placement of the probe can be observed with naked eye at the level of uvula which completely obviates the possibility of erroneous implantation of the probe. Although, debates about the exact positioning of 24-hour $\mathrm{pH}$ monitorization probe still continue, displacement of the probe after its implantation cannot be predicted beforehand which might lead to erroneous results. When data retrieved from $\mathrm{Dx} \mathrm{pH}$ probe are transferred into a computerized system, any desired value can be determined as a baseline $\mathrm{pH}$ and relevant calculations can be performed..$^{[3-6,17-20]}$ In an investigation performed on 55 asymptomatic volunteers, Gloub et al ${ }^{[5]}$ reported parallelism between data obtained by $\mathrm{Dx} \mathrm{pH}$ and standard dualprobe monitorization technique. In another study conducted in Emory University (Atlanta, 2007) $\mathrm{Dx} \mathrm{pH}$ probe was compared to gold standard dual-probe 24-hour and detected mean $\mathrm{pH}$ measurements at the end of a 24-hour monitorization period (excl. meal and sleeping times) as 6.0 (standard dual-probe) and 7.0 (Dx $\mathrm{pH}$ probe). $\mathrm{Dx} \mathrm{pH}$ probe successfully picked up 18 of 20 episodes of GER, while the remaining 2 episodes were detected by a standard probe. This phenomenon demonstrates that $\mathrm{Dx} \mathrm{pH}$ probe provides reliable data related to LPR attacks.

Laryngeal mucosa is very vulnerable to acidic exposure and experimental studies have demonstrated that even one time exposure to acid refluxate can cause ulcerations in vocal cords. ${ }^{[2]}$ However 24-hour $\mathrm{pH}$ monitorization is not sufficiently sensitive to detect these brief episodes of reflux. These observations can explain the reason for variable results obtained. In the literature various studies have proposed different criteria for the discrimination between physiologic and pathologic levels of LPR so as to decide for abnormal LPR at the laryngopharyngeal level. Some laboratories consider a single or two LPR attacks as pathologic and use their predetermined cut-off values for percentage of exposure times recorded under $\mathrm{pH} 4$ conditions. In our study, a sudden and rapid deviation (0.5-2 secs) from the predetermined baseline $\mathrm{pH}$ was defined as a $\mathrm{pH}$ event. In the control group, $0.07 \%$ of the 24 -hour monitorization, $\mathrm{pH}$ attacks were detected. This percentage indicates a statistically significant increase of $7.35 \%$ when compared with the patient group $(\mathrm{p}<0.05)$. Therefore in our study, normal cut-off values were predetermined and case studies were conducted in parallel with these outcomes. Using a multidisciplinary approach symptom scores, readings of reflux monitor and outcomes of empirical treatment are considered in combination so as to make the most appropriate approach to establish the diagnosis of LPR. 
Another influential factor on the frequency of reflux is the potential gastric fluid regurgitation due to relaxation of the lower esophageal sphincter or increased intraabdominal pressure. Gastric contents, posture and gravitational forces are effective on this mechanism. As classical information, contrary to GER, in LPR, reflux events in the upright position are more numerous than those in the supine position. However in various studies contradictory outcomes have been reported. Ouatu-Lascar et al. ${ }^{[2]}$ and Freidin et al.$^{[23]}$ reported higher number of reflux attacks in the upright position. Portale et al. ${ }^{[24]}$ refuted existence of any correlation between reflux and supine or upright position. In our study, data obtained in upright and supine positions were recorded and evaluated separately without any statistically significant difference between these two groups as for number of $\mathrm{pH}$ events. In our study, acid exposure times were analyzed and differences between normal cases and patients were evaluated. In healthy cases, 24-hour monitorization test detected mean acid exposure time as 57.7 seconds. Even though some authors have reported that once daily exposure to acid reflux can induce ulceration in vocal cords, literature lacks sound information about the exact duration of the acid exposure which could induce mucosal damage.

As literature surveys reveal, RFS and RSI have been used separately for the diagnosis of LPR. Applicability and preferability in the diagnosis of LPR has been emphasized ${ }^{[18,20]}$ Still limited number of studies have applied monitorization with Dx $\mathrm{pH}$ probe to substantiate RFS and RSI findings for the establishment of LPR diagnosis. In our study, when clinical and physical examination, laryngeal endoscopy, together with application of RSI and RFS measurement tools before diagnosis and treatment of LPR were realized, $\mathrm{pH}$ measurements with $\mathrm{Dx} \mathrm{pH}$ pharyngeal probe yielded significant diagnostic information favouring LPR.

\section{Conclusion}

This study has demonstrated that data obtained for LPR and the control groups by using RFS and RSI scoring systems suggest that monitorization with oropharyngeal probe can yield reliable diagnostic information leading to the diagnosis of LPR. Besides, thanks to this system, unnecessary drug use is avoided and an easily applicable diagnostic tool in the setting of outpatient clinics has been introduced. Improved patient compliance is its another advantage. In conclusion, addition of objective data to RSI and RFS test scores can ensure a better approach to diagnosis and treatment of LPR. In larger scale controlled studies to be conducted in the future, this combined approach should be evaluated and relevant sensitivity and specificity studies should be performed.

Conflict of Interest: No conflicts declared.

\section{References}

1. Rouev P, Chakarski I, Doskov D, Dimov G, Staykova E. Laryngopharyngeal symptoms and gastroesophageal reflux disease. J Voice 2005;19:476-80.

2. Belafsky PC, Postma GN, Koufman JA. Validity and reliability of the reflux symptom index (RSI). J Voice 2002;16:274-7.

3. Belafsky PC, Postma GN, Koufman JA. The validity and reliabilily of the reflux finding score (RFS). Laryngoscope 2001;111: 1313-7.

4. Chheda NN, Seybt MW, Schade RR, Postma GN. Normal values for pharyngeal $\mathrm{pH}$ monitoring. Ann Otol Rhinol Laryngol 2009;118:166-71.

5. Golub JS, Johns MM 3rd, Lim JH, DelGaudio JM, Klein AM. Comparison of an oropharyngeal $\mathrm{pH}$ probe and a standard dual $\mathrm{pH}$ probe for diagnosis of laryngopharyngeal reflux. Ann Otol Rhinol Laryngol 2009;118:1-5.

6. Wiener GJ, Tsukashima R, Kelly C, et al. Oropharyngeal pH monitoring for the detection of liquid and aerosolized supraesophageal gastric reflux. J Voice 2009;23:498-504.

7. Ayazi S, Lipham JC, Hagen JA, et al. A new technique for measurement of pharyngeal ph: normal values and discriminating ph threshold. J Gastrointest Surg 2009;13:1422-9.

8. Koufman JA. The otolaryngologic manifestations of gastroesophageal reflux disease (GERD): a clinical investigation of 225 patients using ambulatory 24-hour $\mathrm{pH}$ monitoring and an experimental investigation of the role of acid and pepsin in the development of laryngeal injury. Laryngoscope 1991;101(4 Pt 2 Suppl 53):1-78.

9. Green WE, Castell JA, Castell DO. Upper esophageal sphincter pressure recording: is an oval manometry catheter necessary? Dysphagia 1988;2:162-5.

10. Koufman JA, Amin MR, Panetti M. Prevalence of reflux in 113 consecutive patients with laryngeal and voice disorders. Otolaryngol Head Neck Surg 2000;123:385-8.

11. Ossakow SJ, Elta G, Colturi T, Bogdasarian R, Nostrant TT. Esophageal reflux and dysmotility as the basis for persistent cervical symptoms. Ann Otol Laryngol 1987;96:387-92.

12. Axford SE, Sharp N, Ross PE, et al. Cell biology of laryngeal epithelial defenses healt and disease: preliminary studies. Ann Otol Laryngol 2001;110:1099-108.

13. Koufman JA, Belafsky PC, Bach KK, Daniel E, Postma GN. Prevalence of esophagitis in patients with $\mathrm{pH}$-documented laryngopharyngeal reflux. Laryngoscope 2002;112:1606-9.

14. Wiener GJ, Koufman JA, Wu WC, Cooper JB, Richter JE, Castell DO. Chronic hoarseness secondary to gastroesophageal reflux disease: documentation with 24-h ambulatory $\mathrm{pH}$ monitoring. Am J Gastroenterol 1989;84:1503-8.

15. Yorulmaz İ. Larengofarengeal reflü. KBB Forum (Ankara) 2002;1: 22-34. 
16. Little JP, Matthews BL, Glock MS, et al. Extraesophageal pediatric reflux: 24-hour double-probe $\mathrm{pH}$ monitoring in 222 children. Ann Otol Rhinol Laryngol Suppl 1997;169:1-16.

17. Postma GN, Halum SL. Laryngeal and pharyngeal complications of gastroesophageal reflux disease. GI Motility Online (2006) doi:10.1038/gimo46.

18. Naiboglu B, Durmus R, Tek A, Toros SZ, Egeli E. Do the laryngopharyngeal symptoms and signs ameliorate by empiric treatment in patients with suspected laryngopharyngeal reflux? Auris Nasus Larynx 2011;38:622-7.

19. Oelschlager BK, Eubanks TR, Maronian N, et al. Laryngoscopy and pharyngeal $\mathrm{pH}$ are complementary in the diagnosis of gastroesophageal-laryngeal reflux. J Gastrointest Surg 2002;6:189-94.
20. Friedman M, Hamilton C, Samuelson CG, et al. The value of routine $\mathrm{pH}$ monitoring in the diagnosis and treatment of laryngopharyngeal reflux. Otolaryngol Head Neck Surg 2012;146:952-8.

21. Cherry J, Margulies SI. Contact ulcer of the larynx. Laryngoscope 1968;78:1937-40.

22. Ouatu-Lascar R, Lin OS, Fitzgerald RC, Triadafilopoulos G. Upright versus supine reflux in gastroesophageal reflux disease. J Gastroenterol Hepatol 2001;16:1184-90.

23. Freidin N, Mittal RK, McCallum RW. Does body posture affect the incidence and mechanism of gastro-oesophageal reflux? Gut 1991;32:133-6.

24. Portale G, Peters J, Hsieh CC, et al. When are reflux episodes symptomatic? Dis Esophagus 2007;20:47-52.

This is an open access article distributed under the terms of the Creative Commons Attribution-NonCommercial-NoDerivs 3.0 Unported (CC BYNC-ND3.0) Licence (http://creativecommons.org/licenses/by-nc-nd/3.0/) which permits unrestricted noncommercial use, distribution, and reproduction in any medium, provided the original work is properly cited.

Please cite this article as: Torun MT, Gümüşsoy M, Çukurova İ, Arslan İB, Kandoğan T. A pilot study on diagnosing laryngopharyngeal reflux disease by pharyngeal $\mathrm{pH}$ probe monitoring. J Med Updates 2013;3(3):122-128. 